\title{
MINERAL LIBERATION EVOLUTION AFTER DIFFERENT DEGREES OF COMMINUTION ON ITABIRITES*
}

\author{
Rodrigo Fina Ferreira ${ }^{1}$ \\ Rosa Malena Fernandes Lima²
}

\begin{abstract}
This paper presents a mineral liberation study on two iron ore samples from the Quadrilátero Ferrífero, in Brazil: compact itabirite of low-grade metamorphism (CI) and friable itabirite of high-grade metamorphism (FI). The quartz liberation spectrum for both samples have been obtained through QEMSCAN analyses, carried out for several comminution degrees, to compare the liberation characteristics and to evaluate the evolution of the quartz's liberation degree after fragmentation. The results have shown significant differences in liberation spectrum between the itabirite samples studied. The liberation process of $\mathrm{FI}$ was easier than of $\mathrm{Cl}$, due its high porosity and larger crystal size compared with $\mathrm{Cl}$, which has shown more complex mineral assemblages with low porosity and smaller crystals. The quartz liberation spectrum has shown that grinding at $\mathrm{P}_{95}$ of $0.210 \mathrm{~mm}$ for the FI sample, and of 0.045 $\mathrm{mm}$ for $\mathrm{Cl}$ sample, should result in satisfactory liberation for subsequent concentration step.
\end{abstract}

Keywords: Itabirite; Iron ore; Mineral liberation spectrum; QEMSCAN.

1 Engenheiro de Minas, Msc, Centro de Pesquisas Tecnológicas, Vale S/A, Mariana, MG, Brasil.

2 Engenheira de Minas, Dra, Professora do Departamento de Engenharia de Minas, Escola de Minas da Universidade Federal de Ouro Preto, Ouro Preto, MG, Brasil.

* Contribuição técnica ao $44^{\circ}$ Seminário de Redução de Minério de Ferro e Matérias-primas, 15o Simpósio Brasileiro de Minério de Ferro e 2o Simpósio Brasileiro de Aglomeração de Minério de Ferro, 15 a 18 de setembro de 2014, Belo Horizonte, MG, Brasil. 


\section{INTRODUCTION}

\subsection{Geological Aspects}

Brazil has huge iron ore reserves, such as the Quadrilátero Ferrífero's deposits (Minas Gerais State), where, in addition to the high-grade ores, occurs the quartz itabirites from the Caue Formation, Minas Supergroup, which are banded iron formations formed by the metamorphism of a "laminated rock with chert and iron oxides" as described by Dorr [1]. These rocks are composed mainly of quartz and iron minerals, with some other trace phases. In some mines, the high-grade and friable itabirite are currently exploited. Characterisation studies are being developed to allow the exploitation of compact and poor itabirites. Due to the lower Fe content and the mineralogical associations, the process flowchart for poor itabirite ores is constituted by grinding of the whole run of mine, with subsequent concentration by inverse flotation of quartz to produce pellet feed fines. In this context, mineral liberation studies are important to define the size at which the ore must be comminuted to liberate the mineral quartz and to ensure good performance of the concentration without, however, overgrinding the ore.

As well known, the texture and the arrangement of mineral grains in the rock greatly influence the manner of particle fragmentation and therefore the mineral liberation. Metamorphism and strain processes beyond the supergene processes were the main factors that changed the texture of iron ore from Quadrilátero Ferrífero. The region was subjected to at least two major events of strain and metamorphism which have altered the structural and textural characteristics of the rocks. However, the intensity of metamorphism and deformation was not uniform across the area, varying with the differences in tectonic processes and according to the rocks' rheological behaviour (Rosière et al. [2]; Chemale Jr. et al. [3] and Pires [4]).

The Quadrilátero Ferrífero tectonic events decreased from east to west, and divided the region into two main areas: high strain and low strain (Rosière et al., [2]). Pires [4] proposed the subdivision of the region in four metamorphic zones: Grunerite Zone (GZ), Cummingtonite Zone (CZ), Actinolite Zone (AZ), and Tremolite and Anthophyllite Zone (TAZ). The metamorphic grade increases from the first to last. Figure 1 shows a schematic map of Quadrilátero Ferrífero divided into the areas mentioned above. As concluded by Rosière and Chemale Jr. [5], the deformation gradient follows the metamorphic zoning.

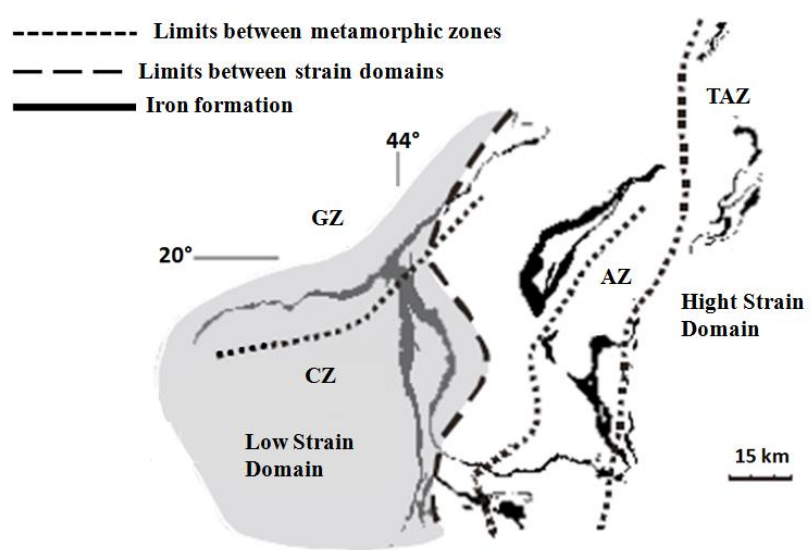

Figure 1. Metamorphic zones and strain domains in the Quadrilátero Ferrífero region. (Rosiére and Chemale Junior, [5]).

* Contribuição técnica ao $44^{\circ}$ Seminário de Redução de Minério de Ferro e Matérias-primas, 15오 Simpósio Brasileiro de Minério de Ferro e 2ํ Simpósio Brasileiro de Aglomeração de Minério de Ferro, 15 a 18 de setembro de 2014, Belo Horizonte, MG, Brasil. 
According to Rosière [6], the increase in the degree of metamorphism contributed to a general increase of the mineral crystals' size. James, apud Dorr [1], stated that the size of quartz and hematite grains varies systematically with the degree of metamorphism. James and Dorr, apud Klein [7], defined the metamorphic grade of the iron formations through the average dimensions of quartz crystals. Therefore, one expects some variation in the crystal size between orebodies from the different zones.

Supergene processes also have changed the itabirite's texture. The friable ore has suffered a natural softening due to the leaching of silica from the jaspilites (or itabirites) that occurs in the aerated zone above the water table, where the percolation of meteoric water is free. These would be conditions in which most of the Fe stays immobile and the silica would be leached, producing a porous and friable rock (Dorr, [1]; Biondi, [8]).

\subsection{Mineral Liberation}

There is an intuitive correlation between fragmentation and mineral liberation, i.e., the finer the fragmentation, the more liberated will be the mineral phases. However, there are two reasons why one should limit the fragmentation to degree of liberation strictly necessary: first, the comminution operations generally represent a high-cost step of mineral processing; second, because the thinner the mineral particles, the worse separation results, overall. The problem that arises in each case is to define the extent to which lead fragmentation obtains sufficient mineral liberation, and this is determined by the recovery and the quality of the concentrate.

According to Gaudin [9], one generally divides the ore dressing in two major stepsliberation and separation-and the second stage would be impractical if the first is not performed successfully. According to that author, this statement is partially true, because it is possible to obtain some degree of separation of locked particles of various types. Following the same concept, Miller et al. [10], and Gottlieb et al. [11], stated that for practical applications in mineral processing, a particle can be considered free if its composition by volume is greater than $90 \%$ of the mineral phase of interest.

Beyond the degree of liberation, it is also important to know the relative amounts of locked particles with different proportions of the mineral of interest and of ganguewhich can be obtained in the liberation spectrum - which consists of a mineralogical composition distribution of particles in a population. This enables the quantification of the amount of free particles of the mineral of interest and the gangue mineral, as well as the relative amounts of locked particles (Neumann et al., [12]; Lin and Miller, [13]). The liberation spectrum may be obtained by various methods, including the QEMSCAN® (FEI Company), an automatic system for quantitative mineralogical analysis, which comprises SEM (Scanning Electron Microscope) and EDS (Energy Dispersive X-ray spectrometers) technology, plus software for automatic image analysis and data processing (Liu et al., [14]; Jaime et al., [15]; Spencer and Sutherland, [16]).

\section{MATERIALS AND METHODS}

Two itabirite samples of different degrees of metamorphism and supergene alteration have been collected-a compact itabirite $(\mathrm{Cl})$ and a friable itabirite $(\mathrm{FI})$ - from the western and eastern regions of Quadrilátero Ferrífero/MG respectively, in mines

* Contribuição técnica ao $44^{\circ}$ Seminário de Redução de Minério de Ferro e Matérias-primas, 15은 Simpósio Brasileiro de Minério de Ferro e 2o Simpósio Brasileiro de Aglomeração de Minério de Ferro, 15 a 18 de setembro de 2014, Belo Horizonte, MG, Brasil. 
currently operated by Vale S/A. Both samples are composed mainly of iron oxides and quartz, with about 50 wt.\% Fe (Table 1).

Table 1. Chemical analysis

\begin{tabular}{|c|c|c|c|c|c|c|c|c|c|}
\hline \multirow{2}{*}{ Sample } & \multicolumn{10}{|c|}{ Chemical Analysis (\%) } \\
\cline { 2 - 10 } & $\mathbf{F e}$ & $\mathrm{SiO}_{2}$ & $\mathbf{P}$ & $\mathrm{Al}_{2} \mathrm{O}_{3}$ & $\mathbf{M n}$ & $\mathrm{TiO}_{2}$ & $\mathbf{C a O}$ & $\mathbf{M g O}$ & $\mathrm{PPC}$ \\
\hline IC & 49.57 & 27.02 & 0.073 & 0.60 & 0.075 & 0.025 & 0.112 & 0.043 & 1.07 \\
\hline IF & 47.37 & 28.86 & 0.071 & 0.43 & 0.086 & 0.021 & 0.005 & 0.001 & 2.43 \\
\hline
\end{tabular}

Each sample, approximately $100 \mathrm{~kg}$, has been crushed in laboratory by a roll crusher in $1.0 \mathrm{~mm}$. After, the crushed ores were splitted through a rotary splitter on representative subsamples and then subjected to laboratory ball grinding, with $\mathrm{P}_{95}$ in several sizes $(0.210 \mathrm{~mm}, 0.150 \mathrm{~mm}, 0.105 \mathrm{~mm}, 0.075 \mathrm{~mm}$ and $0.045 \mathrm{~mm})$. These tests have been carried out with pulp at $65 \mathrm{wt}$ \% solids, in a laboratory mill with 203.2 $\mathrm{mm}$ diameter and $304.8 \mathrm{~mm}$ length, without liners, rotating at $7.54 \mathrm{rad} / \mathrm{s}$. Table 2 shows the distribution of the ball load in the mill.

Table 2. Ball load for the laboratory grinding tests

\begin{tabular}{|c|c|c|c|}
\hline \multicolumn{2}{|c|}{ Diameter (mm) } & \multicolumn{2}{c|}{ Mass (g) } \\
\hline Value & $\begin{array}{c}\text { Acceptable } \\
\text { Deviation }\end{array}$ & Value & $\begin{array}{c}\text { Acceptable } \\
\text { Deviation }\end{array}$ \\
\hline 38,1 & \pm 3 & 11007 & \pm 50 \\
\hline 25,4 & \pm 2 & 3430 & \pm 20 \\
\hline 19,1 & \pm 2 & 1527 & \pm 10 \\
\hline 12,7 & \pm 2 & 913 & \pm 5 \\
\hline
\end{tabular}

The milling time has been controlled by a programmable timer. Several tests have been performed at different times until $\mathrm{P}_{95}$ was achieved in the control size of the test. Such verification has been conducted by wet sieving with a subsample of the ground product obtained in a pulp splitter. After grinding, the samples were divided into pulp splitter, sieved into narrow size fractions, and after, they were subdivided into micro rotary splitter for mineralogical analysis.

Mineralogical characterisation has been performed through QEMSCAN® for all comminution products, with the main objective to assess the evolution of quartz liberation spectrum with different degrees of fragmentation. The mean size of mineral grains (ferrous and gangue) has been measured in equivalent circular diameter by QEMSCAN, from the sample crushed in $1.0 \mathrm{~mm}$.

QEMSCAN® model Quanta 650 (FEl Company), with tungsten source, has been used. Polished sections of $30 \mathrm{~mm}$ diameter have been prepared with the addition of ultrapure graphite in the same particle size range of ore particles for deagglomeration. The PMA analysis method (mineral particle analysis) with twodimensional measurements has been applied, by individual particle, to obtain the quartz liberation spectrum.

* Contribuição técnica ao 44 Seminário de Redução de Minério de Ferro e Matérias-primas, 15ㅇ Simpósio Brasileiro de Minério de Ferro e 2o Simpósio Brasileiro de Aglomeração de Minério de Ferro, 15 a 18 de setembro de 2014, Belo Horizonte, MG, Brasil. 


\section{RESULTS AND DISCUTION}

\subsection{Macroscopic Description}

Figure 2 depicts photographs of macroscopic aspects of compact itabirite $(\mathrm{Cl})$. As can be observed, there is a considerable quantity of blocks (Figure 2A). It is possible to see the typical occurrence of alternating laminations of ferrous minerals and quartz, both very fine-grained, while in most cases it is impossible to differentiate the crystals with the naked eye (Figures $2 \mathrm{~B}, 2 \mathrm{C}$ and $2 \mathrm{D}$ ). There is dispersion of ferrous minerals in laminations composed predominantly of quartz and quartz crystals scattered in predominantly ferruginous layers, i.e., the laminations are not mineralogically homogeneous. The rock is very resistant, and apparently it is hard to comminute it.

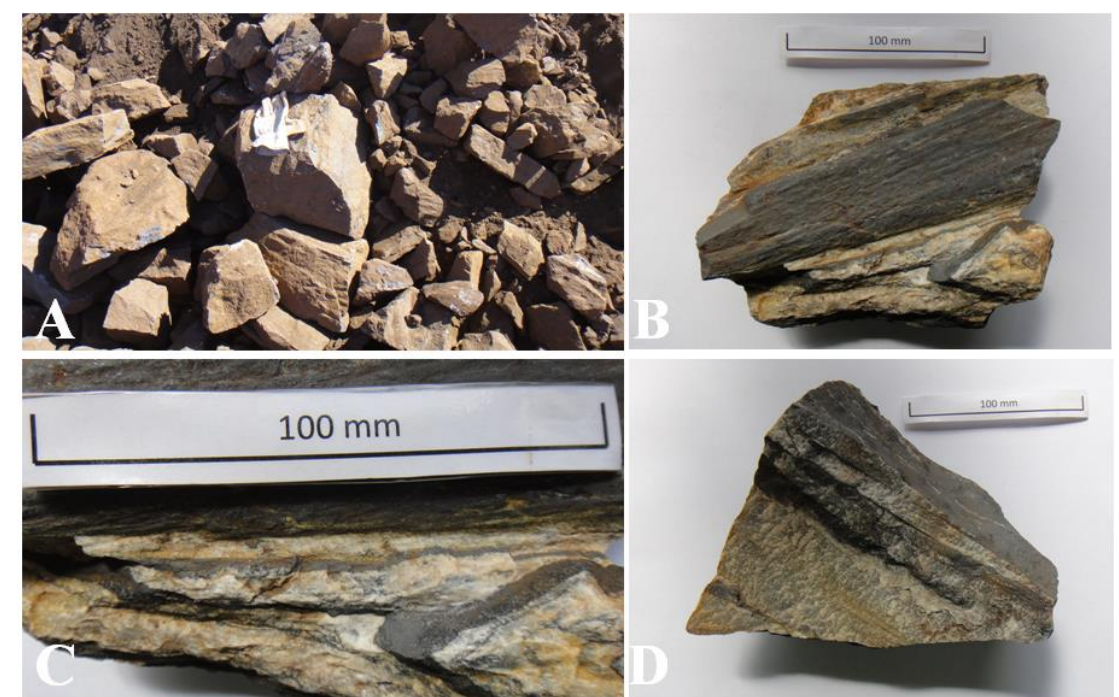

Figure 2. General aspects of the compact itabirite $(A)$ and some fragments of the sample (B, C, D).

Figure 3 shows the friable itabirite $(\mathrm{FI})$. Also found in this sample were ferrous minerals and quartz, predominating in alternating layers and laminations. It is possible to see goethite or limonite lenses, which in some cases is dispersed on the other mineral crystals. The crystals, in general, are noticeably larger, being distinguishable with the naked eye. This fact is evidence of the trend of occurrence of larger crystals occurring in the eastern region of the Quadrilátero Ferrífero, which has been submitted to most intense metamorphism (Rosiere and Chemele Jr., 2000). In the $\mathrm{FI}$ sample, there is a wide variation in the particle size range (Figure $3 \mathrm{~A}$ ). The ore is fragile, it is possible to detach layers by hand (Figure 3B), and when detaching these layers, a considerable amount of quartz crystals is easily detached from the rock (Figure 3D).

\footnotetext{
* Contribuição técnica ao 44 Seminário de Redução de Minério de Ferro e Matérias-primas, 15ํ Simpósio Brasileiro de Minério de Ferro e $2^{\circ}$ Simpósio Brasileiro de Aglomeração de Minério de Ferro, 15 a 18 de setembro de 2014, Belo Horizonte, MG, Brasil.
} 

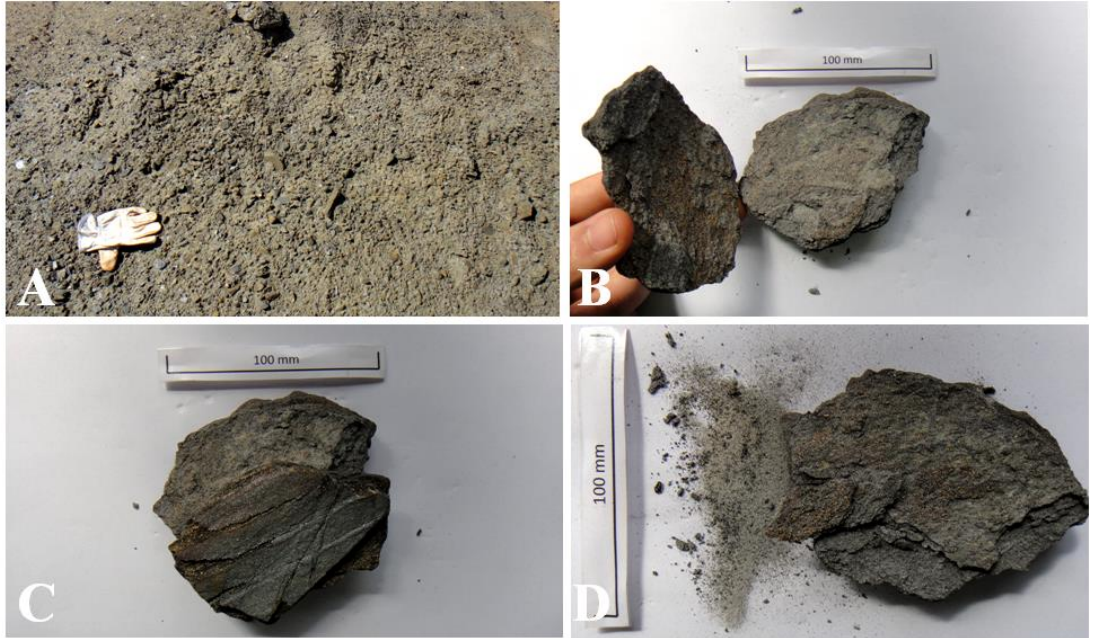

Figure 3. General aspects of the friable itabirite $(A)$ and some fragments of the sample $(B, C, D)$.

\subsection{Size Distribution of the Comminuted Samples}

The particle size distributions of the comminuted samples are grouped in Figures 4 and 5 , for $\mathrm{Cl}$ and $\mathrm{Fl}$ respectively. As can be observed, all specifications in grain size control proposed for the study have been met: P95 of $0.210 \mathrm{~mm}, 0.150 \mathrm{~mm}, 0.105$ $\mathrm{mm}, 0.075 \mathrm{~mm}$ and $0.045 \mathrm{~mm}$.

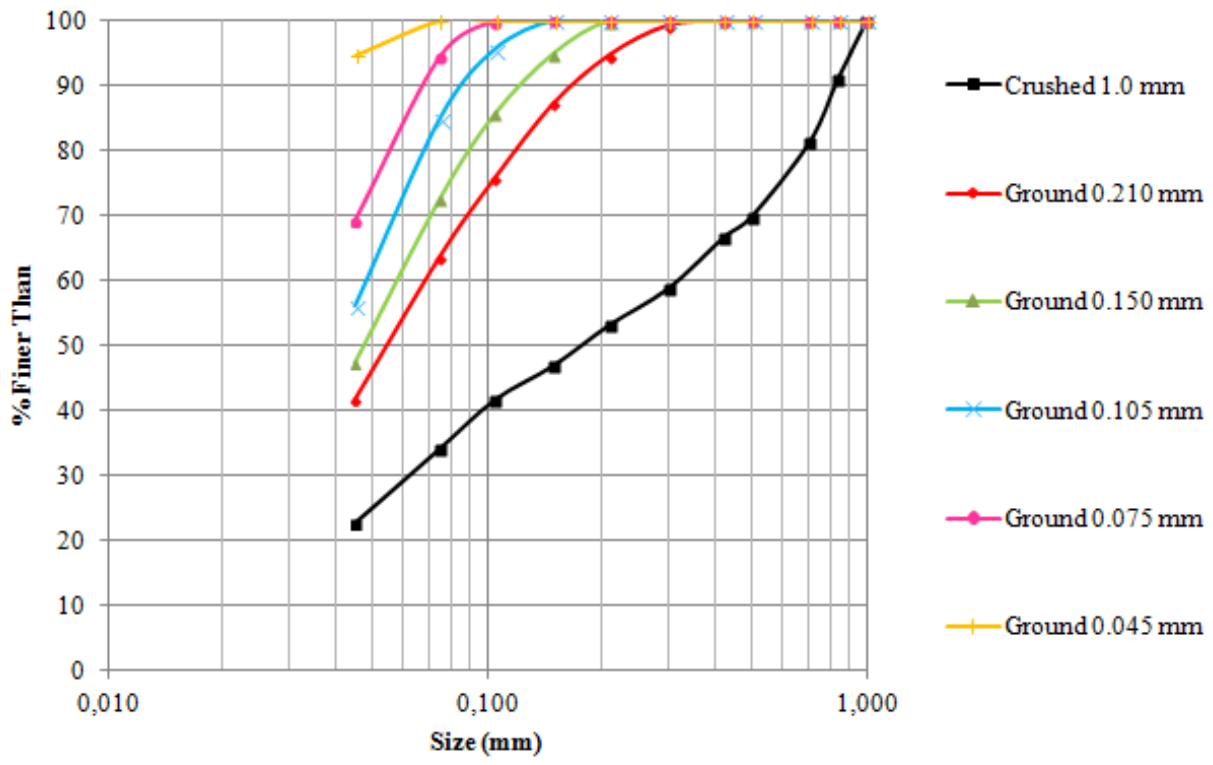

Figure 4. Size distribution for the different degrees of comminution - compact itabirite.

\footnotetext{
* Contribuição técnica ao $44^{\circ}$ Seminário de Redução de Minério de Ferro e Matérias-primas, 15ํ Simpósio Brasileiro de Minério de Ferro e 2o Simpósio Brasileiro de Aglomeração de Minério de Ferro, 15 a 18 de setembro de 2014, Belo Horizonte, MG, Brasil.
} 


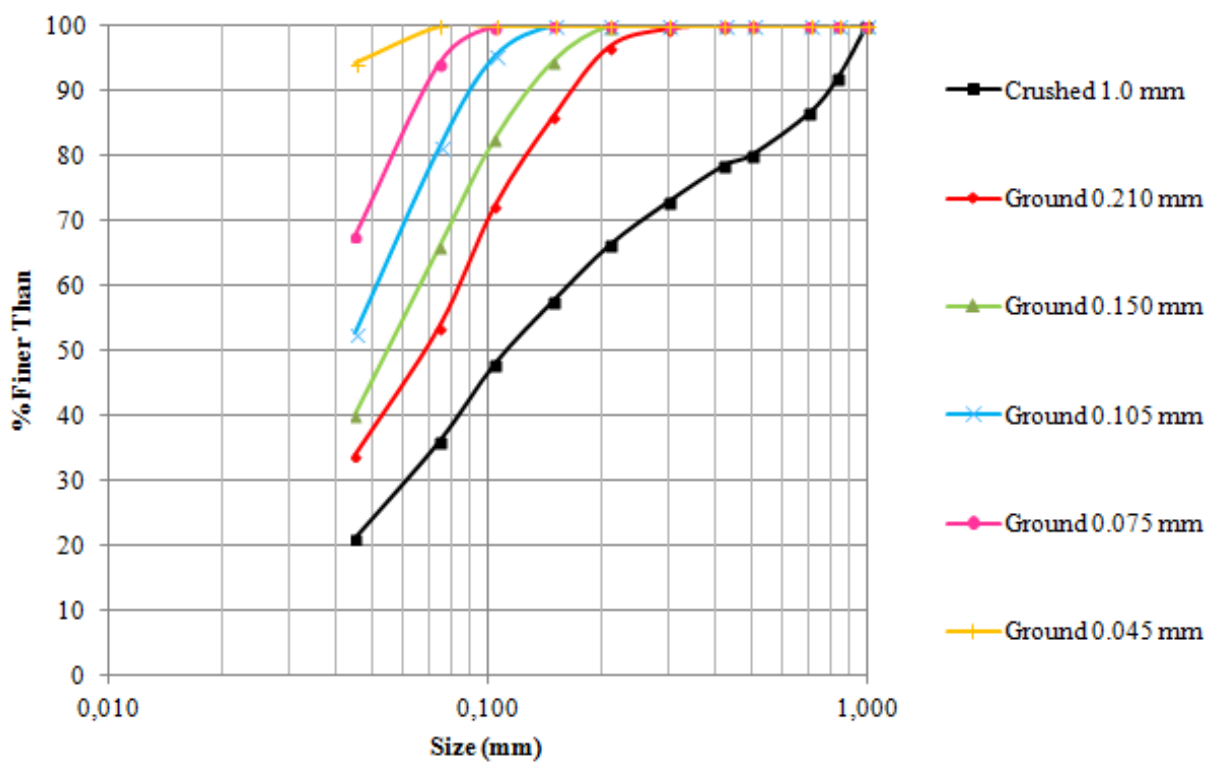

Figure 5. Size distribution for the different degrees of comminution - friable itabirite.

\subsection{Crystal Size}

The global average size of the crystals of ferrous minerals and quartz are presented in Table 3. As can be observed, even with some variations in certain size fractions, it was found that, in general, the crystals are larger in the FI sample compared to the $\mathrm{Cl}$ sample, for both ferrous and gangue minerals, as already observed in the macroscopic evaluation. This difference is attributed to the FI sample from the east region of Quadrilátero Ferrífero, which was submitted to higher intensity of metamorphism; these data corroborate the statements of Rosiere [6] and James (1955) on the correlation between metamorphic grade and crystal minerals size. Of course, it is noteworthy that the comminution at $1.0 \mathrm{~mm}$ may have reduced the differences in crystal size between the two samples.

Table 2. Crystal size for the samples crushed at $1.0 \mathrm{~mm}$

\begin{tabular}{|c|c|c|c|c|c|c|c|c|c|}
\hline \multirow[b]{2}{*}{ Sample } & \multirow[b]{2}{*}{ Mineral } & \multicolumn{8}{|c|}{ Size $\mu \mathrm{m}$} \\
\hline & & $\begin{array}{c}-1000+500 \\
\mu \mathrm{m}\end{array}$ & $\begin{array}{c}-500+210 \\
\mu \mathrm{m}\end{array}$ & $\begin{array}{c}-210+150 \\
\mu \mathrm{m}\end{array}$ & $\begin{array}{c}-150+105 \\
\mu \mathrm{m}\end{array}$ & $\begin{array}{c}-105+75 \\
\mu \mathrm{m}\end{array}$ & $\begin{array}{c}-75+45 \\
\mu \mathrm{m}\end{array}$ & $-45 \mu \mathrm{m}$ & Average \\
\hline IC & \multirow{2}{*}{ Quartz } & 79,73 & 55,61 & 53,18 & 42,60 & 47,70 & 38,00 & 19,09 & 51,11 \\
\hline IF & & 156,49 & 117,66 & 110,88 & 82,95 & 68,09 & 46,19 & 16,68 & 88,63 \\
\hline IC & \multirow{2}{*}{$\begin{array}{c}\mathrm{Fe} \\
\text { Oxides }\end{array}$} & 123,00 & 97,02 & 87,22 & 75,30 & 62,88 & 46,46 & 22,09 & 77,68 \\
\hline IF & & 188,16 & 124,99 & 102,72 & 79,65 & 60,19 & 45,64 & 17,80 & 94,45 \\
\hline
\end{tabular}

\subsection{Quartz Liberation Spectrum}

The quartz liberation spectrum for $\mathrm{Cl}$ and $\mathrm{FI}$ samples obtained through QEMSCAN® are shown in Figures 6 and 7 , including all of the comminuted samples.

\footnotetext{
* Contribuição técnica ao $44^{\circ}$ Seminário de Redução de Minério de Ferro e Matérias-primas, $15^{\circ}$ Simpósio Brasileiro de Minério de Ferro e $2^{\circ}$ Simpósio Brasileiro de Aglomeração de Minério de Ferro, 15 a 18 de setembro de 2014, Belo Horizonte, MG, Brasil.
} 


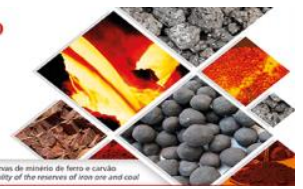

$(100 \%<1,00 \mathrm{~mm})$

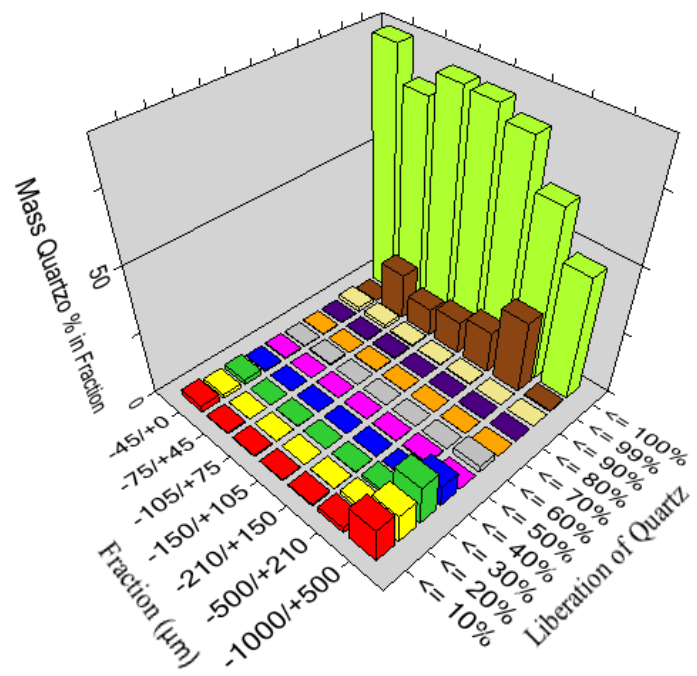

$(95 \%<0,150 \mathrm{~mm})$

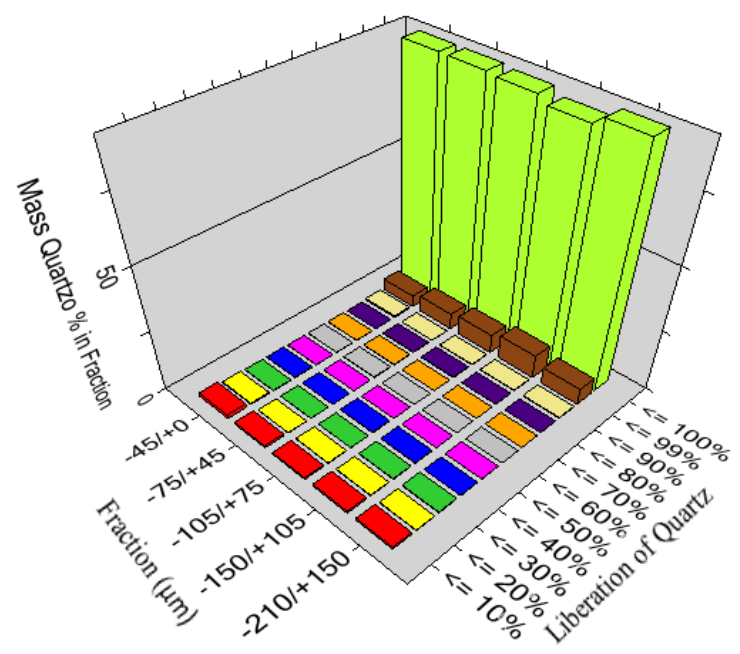

$(95 \%<0,075 \mathrm{~mm})$

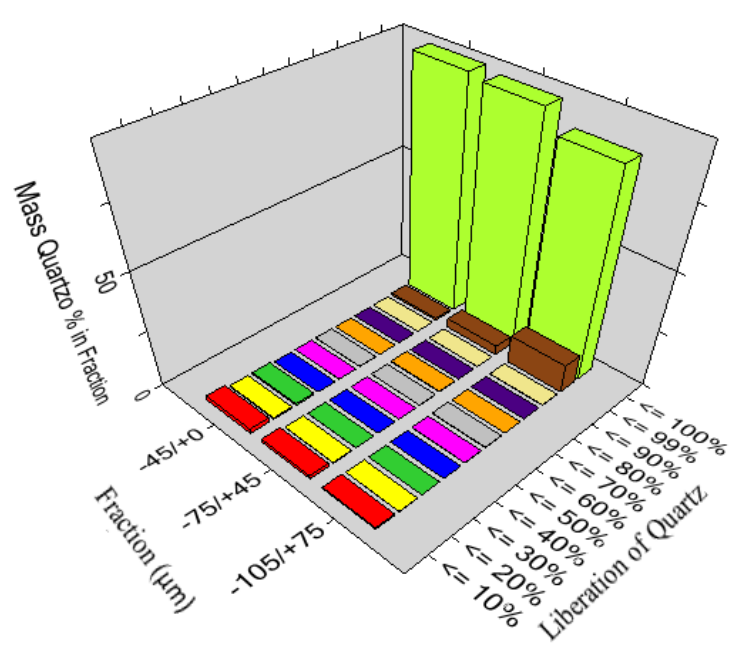

$(95 \%<0,210 \mathrm{~mm})$

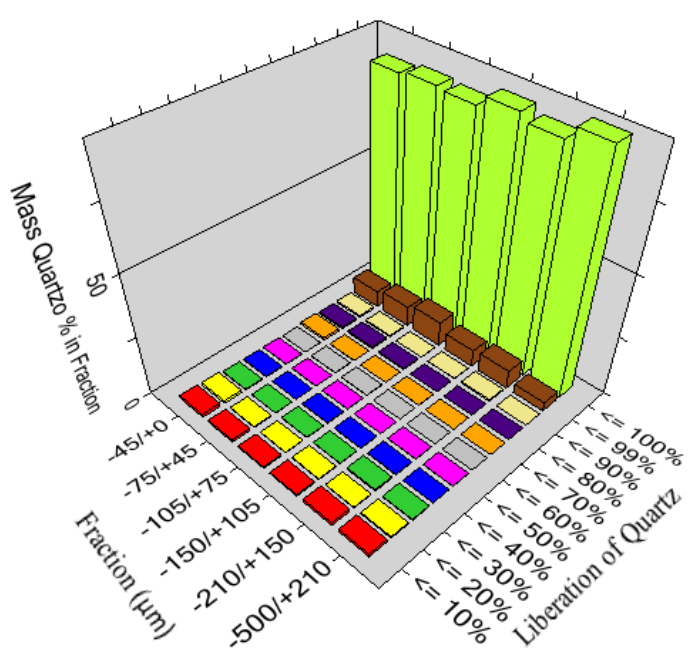

$(95 \%<0,105 \mathrm{~mm})$

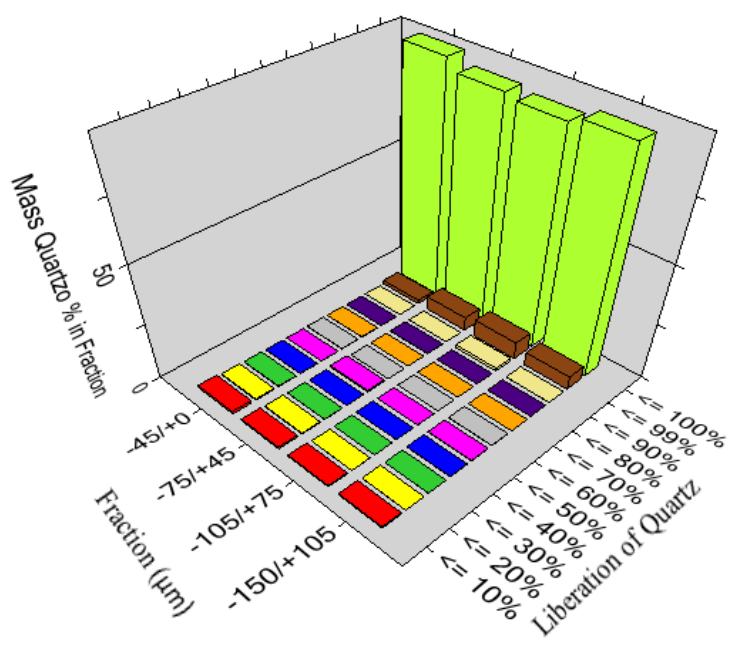

$(95 \%<0,045 \mathrm{~mm})$

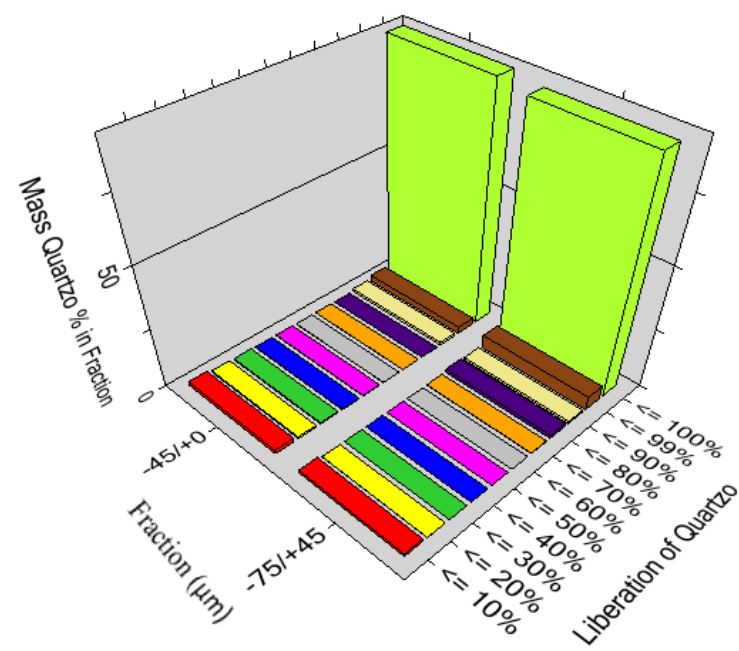

Figure 6. Quartz liberation spectrums for the friable itabirite sample.

* Contribuição técnica ao 44 Seminário de Redução de Minério de Ferro e Matérias-primas, 15 Simpósio Brasileiro de Minério de Ferro e 2o Simpósio Brasileiro de Aglomeração de Minério de Ferro, 15 a 18 de setembro de 2014, Belo Horizonte, MG, Brasil. 

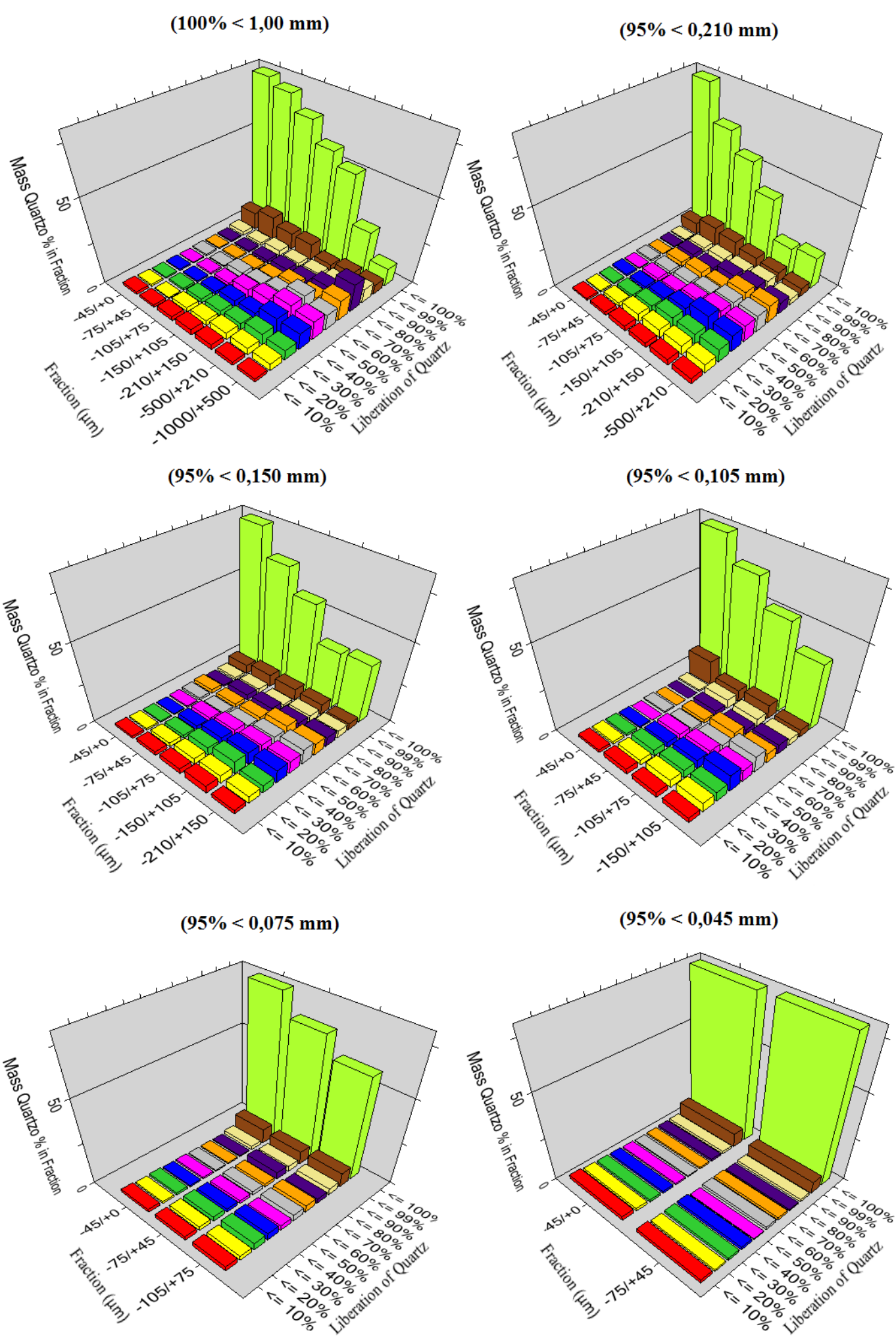

Figure 7. Quartz liberation spectrums for the compact itabirite sample.

From the liberation spectrum of the FI sample crushed to $1.0 \mathrm{~mm}$ (Figure 6), it was found that in the fraction $-1.0+0.5 \mathrm{~mm}$, approximately $48 \%$ of quartz is free, and the remainder is distributed mainly in particles of less than $40 \%$ of quartz in the composition. For sizes less than $0.5 \mathrm{~mm}$, the percentage of free quartz rises further, and it is no longer observed large percentage of particles with composition of quartz

* Contribuição técnica ao 44 Seminário de Redução de Minério de Ferro e Matérias-primas, 15ํ Simpósio Brasileiro de Minério de Ferro e $2^{\circ}$ Simpósio Brasileiro de Aglomeração de Minério de Ferro, 15 a 18 de setembro de 2014, Belo Horizonte, MG, Brasil. 
less than 40 wt.\%, but above 90 wt.\%. In the fraction size $-0.21+0.15 \mathrm{~mm}$, about $80 \%$ of quartz is free, and in the lower size fractions the degree of liberation exceeds $85 \%$, except for the fraction $-0.075+0.045 \mathrm{~mm}$, in which the percentage of free quartz kicks to $78 \%$, probably due to some measurement deviation. The degree of liberation reaches $91 \%$ in the fraction $-0.045 \mathrm{~mm}$.

For the $\mathrm{FI}$ sample, there has been a considerable increase in the liberation of quartz with grinding in $0.210 \mathrm{~mm}$, for all size classes (Figure 6). The liberation spectrum has shifted almost entirely to the classes upper to $99 \%$ quartz in the particle, and thus occurred after grinding in the other control sizes, being obtained very similar distributions. These data have shown that is easy to liberate the crystals in the friable itabirite, and this fact may be associated with the textural characteristics of the ore, as the significant occurrence of connected pores forming zones of weakness between the crystals, as well as the crystal size, which is larger in this case.

The liberation spectrum of the $1.0 \mathrm{~mm}$ crushed product of the $\mathrm{Cl}$ sample (Figure 7) is more complex when compared to the FI sample (Figure 6). The liberation degree of quartz in the $\mathrm{Cl}$ sample is lower than that of the $\mathrm{Fl}$ sample in all size fractions. In thicker fractions, $-1.0+0.5 \mathrm{~mm}$, there is a broad spectrum, with particles distributed across all classes of composition, with the highest concentration between 80 and $40 \%$ classes. The liberation degree of this fraction is only $11 \%$. For the finer size fractions, the degree of liberation has increased gradually, peaking at $80 \%$ in the fraction - $0.045 \mathrm{~mm}$.

Despite the presence of a large proportion of free quartz particles from the first degree of comminution $(1.0 \mathrm{~mm})$, the $\mathrm{Cl}$ sample spectrum remained more distributed until grinding in $0.075 \mathrm{~mm}$. The spectrum relating to $0.045 \mathrm{~mm}$ ground product presents the vast majority of the particles into the $99 \%$ and $100 \%$ classes. These data have shown that is relatively difficult to liberate mineral phases in the compact itabirite, reflecting the textural characteristics of the ore, whose particles are more resistant, along with less porosity, and smaller and overlapping crystals.

For both studied samples, it was observed that a considerable proportion of free quartz particles were already in the early stages of comminution. This fact highlights the importance of applying pre-concentration processes in the processing of these ores. The free particles of the gangue mineral must be removed as soon as possible to minimise energy consumption in fragmentation. Every effort to reduce size for liberation must be applied to locked particles.

Based on the results presented in Figures 6 and 7 and considering that particles in which quartz proportion is more than $90 \%$ are free [10,11], grinding in $0.210 \mathrm{~mm}$ and $0.045 \mathrm{~mm}$, for $\mathrm{FI}$ and for $\mathrm{Cl}$ respectively, should result in a satisfactory degree of liberation for subsequent concentration through inverse flotation.

\section{CONCLUSION}

Based on liberation studies carried out with the iron ore samples, friable and compact itabirite, it was concluded that there are significant differences between the two ore samples in mineral liberation characteristics. The easer liberation of quartz on $\mathrm{FI}$ compared with $\mathrm{Cl}$ can be due to its larger crystal size, which implies in the trend to satisfactory degree of liberation by comminution in a coarser size. The $\mathrm{Cl}$ sample has more complex texture, with low porosity and no occurrence of zones of weakness between the crystals, which are smaller, thus making it necessary to apply grinding into finer sizes for satisfactory liberation. The liberation spectrum of the comminuted samples have shown that grinding in $0.210 \mathrm{~mm}$ for FI sample, and $0.045 \mathrm{~mm}$ for $\mathrm{Cl}$

* Contribuição técnica ao $44^{\circ}$ Seminário de Redução de Minério de Ferro e Matérias-primas, 15ㅇ Simpósio Brasileiro de Minério de Ferro e 2o Simpósio Brasileiro de Aglomeração de Minério de Ferro, 15 a 18 de setembro de 2014, Belo Horizonte, MG, Brasil. 
sample, should result in a satisfactory liberation for subsequent concentration, assuming that particles with more than $90 \%$ quartz can be considered free.

\section{Acknowledgements}

Financial support by the Vale S.A. and CNPq scholarship for one author is gratefully acknowledged.

\section{REFERÊNCIAS}

1 Dorr JVN. 1959. Esboço Geológico do Quadrilátero Ferrífero de MG. In: DNPM-USGS. Publicação Especial 1, 120 p.

2 Rosière CA, Chemale JrF, Guimarães MLV. 1993. Um modelo para a evolução microestrutural dos minérios de ferro do Quadrilátero Ferrífero. Parte I - estruturas e recristalização. Geonomos, 1(1): p. 65-84.

3 Chemale JrF, Rosière CA, Endo I. 1991. Evolução tectônica do Quadrilátero Ferrífero, Minas Gerais - Um Modelo. Pesquisas UFRGS, Porto Alegre, 18 (2): p. 104 - 127.

4 Pires FRM. 1995. Textural and mineralogical variations during metamorphism of the Proterozoic Itabira Iron Formation in the Quadrilátero Ferrífero, Minas Gerais, Brazil. Anais da Academia Brasileira de Ciências, 67 (1), p. 77-105.

5 Rosière CA, Chemale Jr.F. 2000. Itabiritos e minérios de ferro de alto teor do Quadrilátero Ferrífero - uma visão geral e discussão. Geonomos, 8(2): p. 27-43.

6 Rosière CA. 1996. Um modelo para evolução microestrutural de minérios de ferro do Quadrilátero Ferrífero. Parte II - Trama, textura e anisotropia de susceptibilidade magnética. Geonomos, v.4, n.1, p.61-75.

$7 \quad$ Klein C. 1973. Changes in mineral assemblages with metamorphism of some banded Precambrian iron-formations. Economic Geology, 68, p.1075-1088.

8 Biondi JC. 2003. Processos Metalogenéticos e os Depósitos Minerais Brasileiros. São Paulo: Oficina de Textos, $528 \mathrm{p}$.

9 Gaudin AM. 1939. Principles of Mineral Dressing. New Delhi: Tata McGraw-Hill Publishing Company Ltd, $554 \mathrm{p}$

10 Miller PR, Reid AF, Zuiderwyk MA. 1982. QEMSEM image analysis in the determination of modal assays, mineral associations and mineral liberation, in Proceedings XIV International Mineral Processing Congress, Toronto, Canadá, VIII 3, p. 1-3.

11 Gottlieb P, Adair BJI, Wilkie,GJ. QEMSEM liberation indices for grinding classification and flotation, in AusIMM V Mill Operator`s Conference, Roxby Downs, Australia, 1994, p. 5-13.

12 Neumann R, Schneider CL. 2010. Caracterização Tecnológica de Minérios Parte II. In Tratamento de Minérios, Centro de Tecnologia Mineral - CETEM, 5ª Edição, capítulo 3, p. 85-139.

13 Lin CL, Miller JD. 1996. Cone beam X-ray microtomography for three-dimensional liberation analysis in the 21st century. International Journal of Mineral Processessing No 47, p. 61-73.

14 Liu Y, Gupta R, Wall T. 2007. A comparison of CCSEM and QEMSCAN analysis of pulverized coal, Cooperative Research Centre for Coal in Sustainable Development, Research Report 71, University of Newcastle, Australia.

15 Jaime P, Gottlieb P, Butcher A, Dobbe R. 2009. The Applicability of automated mineralogy on process planning, process optimisation, quality control, audit studies and trouble shooting, with emphasis on processing plants, Proceedings of Procemin 2009 Conference, Santiago, Chile, 2009.

16 Spencer S, Sutherland D. 2000. Stereological correction of mineral liberation grade distributions estimated by single sectioning of particles, Image Anal Stereol 2000;19: 175-182.

\footnotetext{
* Contribuição técnica ao $44^{\circ}$ Seminário de Redução de Minério de Ferro e Matérias-primas, 15ํ Simpósio Brasileiro de Minério de Ferro e $2^{\circ}$ Simpósio Brasileiro de Aglomeração de Minério de Ferro, 15 a 18 de setembro de 2014, Belo Horizonte, MG, Brasil.
} 